\title{
Knowledge and attitude of emergency physician about the emergency management of tooth avulsion
}

\author{
Laila A. Bahammam
}

\begin{abstract}
Background: The aim of the study was to evaluate the knowledge of ER physicians with different specialties, experience and hospital sectors for the management of avulsed teeth in the emergency rooms of eight major hospitals in Jeddah, Saudi Arabia. It also covers their attitude towards receiving further education on tooth avulsion management.

Methods: A cross-sectional survey was conducted at the emergency rooms of eight hospitals in Jeddah from August to December 2015. A self-administered questionnaire consisting of 31 multiple choice questions assessing both knowledge and attitude was distributed to 150 physicians who were working in the ER departments.

Results: Response rate was $81.33 \%$. Data revealed that $45.9 \%$ of the respondents did not have prior knowledge about avulsion. Physicians working in military hospitals had better knowledge about the ER management of avulsion cases than physicians of public hospitals. $80.3 \%$ of participants showed willingness to replant the tooth, however, $65.3 \%$ would not do it by themselves. $42.6 \%$ of the physicians did not know the importance of extra-oral time. Milk was selected as the best transport media for avulsed tooth by $31.1 \%$ of the participants. Regarding physicians' attitude, $95.1 \%$ showed interest in receiving information about the subject.
\end{abstract}

Conclusion: This study revealed that the majority of ER physicians lack the knowledge needed to manage avulsions cases. Hence, educational programs are necessary for ER physicians to provide proper management for those cases.

Keywords: Avulsion, Dental trauma, Emergency management, Traumatic dental injury, Physician, Attitude, Knowledge

\section{Background}

Traumatic injuries to dentoalveolar tissues are considered the most serious oral health problem amongst children and adolescents. One of the types of traumatic dentoalveolar injury is tooth avulsion that is defined as total dislodgment of the tooth from its socket. It represents about $16 \%$ of all traumatic dentoalveolar injuries [1].

Maxillary central incisor is the most affected tooth $[2,3]$ due to their labial projection which make them more susceptible to facial trauma [2]. Moreover, these teeth have minimal resistance to frontal impact among children aged 7-9 years because of the lack of the periodontal ligament's resiliency and the low mineralization of the surrounding bone [2]. Permanent anterior teeth are not only essential for aesthetics but also for phonetics, mastication and

Correspondence: Ibahammam@yahoo.com; Ibahammam@kau.edu.sa Endodontics Department, Faculty of Dentistry, King Abdulaziz University, P. O. Box 80209, Jeddah 21589, Kingdom of Saudi Arabia psychological health of young patients. Hence, immediate and appropriate management of the avulsed tooth by replantation is critical for long term prognosis, especially in children [2]. Failure to replant the tooth will lead to expensive, time-consuming, and complex multidisciplinary approaches [4]. When replantation is not possible, appropriate handling of the avulsed tooth will help to ensure long-term successful outcome [2]. Similarly, incorrect handling and replantation of avulsed tooth will lead to tooth resorption or ankyloses and result in poor prognosis [2].

The prognosis of tooth replantation is dependent on multiple factors; such as time of endodontic intervention, storage media, extra-alveolar period, type of retention employed, and type of drug prescribed. However, the most critical factor for an excellent prognosis is the preservation of viable periodontal ligament cells (PDL) covering the root, this can be established by storing the tooth in a suitable media such as milk, saliva or saline [2]. 
Tooth avulsion usually occurs because of road traffic accidents, falls and other physical impacts. It could happen in schools during sports or because of physical violence. In these situations, parents usually take their children to visit an emergency (ER) physician at the hospital to seek treatment. In such facilities, there is a lack of availability of a full-time dentist [5]. Therefore, to insure proper management of avulsed tooth, it is important for ER physicians to have sufficient knowledge about the emergency management of such cases [6].

There are many studies conducted in several countries that showed medical physicians lack the adequate knowledge about the emergency management of avulsion $[3,7-10]$. Unfortunately, to my knowledge, no study of this type has been conducted in Saudi Arabia so far on the knowledge of ER physicians about the management of tooth avulsion. Therefore, the purposes of this study were to evaluate the knowledge of ER physicians with different specialties, experience and hospital sectors about the management of avulsed teeth in the emergency rooms of eight major hospitals in Jeddah, Saudi Arabia and their attitude toward receiving further education on the emergency management of tooth avulsion.

\section{Methods}

The present study is a cross-sectional survey conducted from August to November 2015. Ethical approval was obtained from local ethical committee (\#037-15). The study targeted physicians that were working in the ER department with the following criteria; ER physicians (Consultant or Specialist), pediatricians (Consultant or Specialist), residents having ER rotations in (ER, Pediatrics, or General Surgery), general practitioner assigned in the $E R$, and medical interns having ER rotations.

Convenient sample was collected from the emergency rooms of six major governmental hospitals and two military hospitals in Jeddah. These were; King Faisal Specialist Hospital, King Abdulaziz University Hospital, King Fahad General Hospital, Al-Thagher Hospital, Al-Aziziyah Maternity and Children Hospital, Jeddah Maternity and Children Hospital, King Fahad Armed Forces Hospital, and the National Guard Hospital. These hospitals were selected because they have an ER department that accept trauma patients.

A self-administered questionnaire with close-ended questions modified from previous studies was used $[5,6$, $11,12]$. The questionnaire consisted of 31 questions divided into three parts; 6,21 and 4 questions in each part respectively. The first part had 6 questions which were about demographic data of the participating physicians, the second part included 21 questions about knowledge related to avulsed tooth and its emergency management, and the last part had 4 questions to evaluate the physician's attitudes towards learning and receiving more information in order to properly manage such injuries [see Additional file 1]. Confidentiality was maintained, as the questionnaire did not require names or contact numbers of the participants. A consent form was attached to the questionnaire explaining the purpose of the study. It was stated that the participation in survey is voluntary and anyone can choose not to participate in the research or exit the survey at any time without penalty and the information provided by the participant in the questionnaire and the results of this study will be used for scholarly purposes only. Also, it was mentioned in the consent that; by answering the questionnaire questions the participant is fully understand the contents of this document and is agreeing to participate in this study.

A total of 150 questionnaires were distributed and the physician's participation was voluntarily. Twenty-eight physicians refused to participate and complete their questionnaires because they were exhausted or busy. Two investigators had the responsibility of distributing and collecting the questionnaires by themselves, in order to ensure its completion process without involving colleagues' consultation.

Data were collected and statistically analyzed using Mann-Whitney U, Kruskal-Wallis H, and Bonferroni tests (SPSS program version 20, SPSS, Chicago, IL, USA).

\section{Results}

\section{Demographic data (Table 1)}

Out of 150 ER physicians in all eight hospitals, 122 responded $(81.33 \%)$. The majority of them were male (68.9\%). The minimum age of the participants was 25 years and the maximum was 55 years. $74.6 \%$ of the participants were between 20 and 39 years old. They were 16 consultants (13.1\%), 24 specialists (19.7\%), 16 general practitioners (13.1\%), 46 residents (37.7\%), and 20 interns (16.4\%). Their specialties were; ER (44.2\%), Pediatrics (32.8\%), General Surgery (6.6\%), and interns (16.4\%). $50.8 \%$ of them were Saudi and $49.2 \%$ were non-Saudi.

\section{Previous knowledge and experience with dental avulsion (Table 2)}

Data revealed that $47.5 \%$ of the respondents did not have prior knowledge regarding the subject. Medical books $(20.5 \%)$ and residency programs $(15.6 \%)$ were the two major sources of information to those who had previous knowledge. With reference to the meaning of tooth avulsion, $68.9 \%$ of the participants knew the correct meaning and $59 \%$ of them mentioned that they came across avulsion cases (Table 2).

\section{Knowledge about re-implantation and extra-oral time (Table 3)}

Most of the physicians $(87.7 \%)$ responded that they would refer or instruct the parent to visit the dentist after avulsion, 
Table 1 Demographic data and knowledge level of the participants

\begin{tabular}{|c|c|c|c|c|c|}
\hline \multirow{2}{*}{$\frac{\text { Demographic data }}{\text { Variables }}$} & & \multirow[b]{2}{*}{$N(\%)$} & \multicolumn{2}{|c|}{ Knowledge Level } & \multirow[b]{2}{*}{$P$ value } \\
\hline & & & Mean(SD) & Median & \\
\hline \multirow[t]{2}{*}{ Gender } & Male & $84(68.9)$ & $61.9(21.3)$ & 66.7 & 0.234 \\
\hline & Female & $38(31.1)$ & $58.5(20.4)$ & 61.1 & \\
\hline \multirow[t]{4}{*}{ Age } & $20-<30$ & $45(36.9)$ & $46.1(17.7)$ & 41.7 & 0.002 \\
\hline & $30-<40$ & $46(37.7)$ & $67.6(17.3)$ & 72.2 & \\
\hline & $40-<50$ & 19 (15.6) & $69.8(17.3)$ & 77.8 & \\
\hline & $\geq 50$ & $12(9.8)$ & $87.5(4.9)$ & 86.1 & \\
\hline \multirow[t]{2}{*}{ Nationality } & Saudi & $62(50.8)$ & $57.3(24.0)$ & 61.1 & 0.165 \\
\hline & Non-Saudi & $60(49.2)$ & $64.4(16.8)$ & 66.7 & \\
\hline \multirow[t]{4}{*}{ Specialty } & ER & $54(44.2)$ & $69.7(16.8)$ & 77.8 & 0.000 \\
\hline & Pediatric & $40(32.8)$ & $59.7(20.8)$ & 61.1 & \\
\hline & General Surgery & $8(6.6)$ & $45.8(19.9)$ & 50 & \\
\hline & Intern & $20(16.4)$ & $38.9(15.2)$ & 38.9 & \\
\hline \multirow[t]{5}{*}{ Experience Level (occupation) } & Consultant & $16(13.1)$ & $82.6(5.3)$ & 83.3 & 0.000 \\
\hline & Specialist & $24(19.7)$ & $70.4(13.2)$ & 72.2 & \\
\hline & Resident & $46(37.7)$ & $51.6(19.6)$ & 55.6 & \\
\hline & General Practitioner & $16(13.1)$ & $73.6(14.6)$ & 72.2 & \\
\hline & Intern & $20(16.4)$ & $42(16.9)$ & 38.9 & \\
\hline \multirow[t]{2}{*}{ Previous exposure to avulsion cases } & Yes & $72(59)$ & $67.6(17.67)$ & 72.22 & 0.000 \\
\hline & No & $50(41)$ & $51.1(21.76)$ & 50 & \\
\hline \multirow[t]{2}{*}{ Hospitals } & Public & $62(50.8)$ & $56.6(19.2)$ & 55.6 & 0.009 \\
\hline & Military & 60 (49.2) & $65.2(22)$ & 72.2 & \\
\hline
\end{tabular}

Table 2 Previous knowledge and experience with dental avulsion

\begin{tabular}{|c|c|c|c|}
\hline Questions & Options & Frequency & Percent \\
\hline \multirow[t]{4}{*}{ What is tooth avulsion? } & $\begin{array}{l}\text { Total dislodgement of intact tooth out of its socket due } \\
\text { to any trauma }\end{array}$ & 84 & 68.9 \\
\hline & $\begin{array}{l}\text { Dislodgement of fractured segment of the tooth due to } \\
\text { any trauma }\end{array}$ & 17 & 14 \\
\hline & Tooth fracture due to any trauma & 5 & 4.1 \\
\hline & Don't know & 16 & 13 \\
\hline \multirow{2}{*}{$\begin{array}{l}\text { Do you have any prior knowledge about the management of } \\
\text { avulsed tooth? }\end{array}$} & Yes & 64 & 52.5 \\
\hline & No & 58 & 47.5 \\
\hline \multirow[t]{5}{*}{ If yes, what was your source of information? } & Residency program & 19 & 15.6 \\
\hline & Health talks on TV or radio & 7 & 5.7 \\
\hline & Medical books & 25 & 20.5 \\
\hline & Others & 13 & 10.7 \\
\hline & $N A^{a}$ & 58 & 47.5 \\
\hline \multirow{2}{*}{$\begin{array}{l}\text { Have you ever come across a patient with avulsed tooth } \\
\text { (knocked out)? }\end{array}$} & Yes & 72 & 59.0 \\
\hline & No & 50 & 41.0 \\
\hline
\end{tabular}


Table 3 Knowledge about re-implantation and extra-oral time

\begin{tabular}{|c|c|c|c|}
\hline Questions & Options & Frequency & Percent \\
\hline \multirow{2}{*}{$\begin{array}{l}\text { Did you or would you refer the child or instruct the parents to } \\
\text { go to the dentist after avulsion? }\end{array}$} & Yes & 107 & 87.7 \\
\hline & No & 15 & 12.3 \\
\hline \multirow[t]{6}{*}{ If YES, When will you advise the parents to go to the dentist? } & Immediately & 66 & 54.0 \\
\hline & Next day & 23 & 18.8 \\
\hline & After few days, when child is comfortable & 2 & 1.6 \\
\hline & Only if any pain or other symptoms are noticed & 13 & 10.6 \\
\hline & $N A^{a}$ & 15 & 12.0 \\
\hline & Missing & 4 & 3.0 \\
\hline \multirow[t]{2}{*}{ Do you think that the avulsed permanent tooth can be put back? } & Yes & 97 & 79.5 \\
\hline & No & 25 & 20.5 \\
\hline \multirow[t]{3}{*}{ If YES, will you do it by yourself? } & Yes & 34 & 27.9 \\
\hline & No & 63 & 51.6 \\
\hline & $N A^{a}$ & 25 & 20.5 \\
\hline \multirow[t]{3}{*}{ Is extra oral time is important? } & Yes & 63 & 51.6 \\
\hline & No & 6 & 4.9 \\
\hline & Don't know & 53 & 43.5 \\
\hline
\end{tabular}

${ }^{\mathrm{a} N A}$ answered (No) to the previous question

however, $54 \%$ of them would advise the parents to go immediately. When participants were asked about the possibility of replanting the tooth, $79.5 \%$ answered positively, however, $27.9 \%$ of them would do it by themselves. Furthermore, slightly over half of the physicians (51.6\%) knew the importance of extra-oral time (Table 3).

\section{Handling, cleaning and transport media (Table 4)}

In relation to tooth handling, $51.6 \%$ of physicians would hold the avulsed tooth from the crown. Almost half of the physicians (48.4\%) chose to rinse the tooth under running water if it was covered with soil before replanting it.

Milk was selected as the best transport media for avulsed tooth by $31.1 \%$ of the participants, followed by saline (21.3\%). However, $21.3 \%$ of the physicians decided to wrap the tooth in paper or gauze (Table 4).

\section{Physicians attitude (Table 5)}

Most of the participants (63.1\%) believed that they have an inadequate level of information about traumatic dental injuries. Accordingly, 95.1\% of them had shown interest in receiving more information in order to properly manage such injuries and all of them (100\%) agreed on the importance of learning about this subject (Table 5).

\section{Groups' comparisons on knowledge level (Table 1)}

Data were not normally distributed; therefore nonparametric tests were used (Table 1).

To compare mean knowledge of different physicians' gender, nationality, previous exposure to avulsion cases and different hospital sectors, Mann-Whitney U test was used. Results showed that there was no statistical significant difference between male and female $(p=0.234)$, nor between Saudi and non-Saudi Physicians $(p=0.165)$. However, there was a statistical significant difference between physicians with previous exposure to avulsion cases and those with no experience $(p=0.000)$. Physicians who came across avulsion cases had better knowledge about the ER management of such cases than those with no experience. Moreover, there was a statistical significant difference between physicians working in military and public hospitals $(p=0.009)$. Results showed that physicians working in military hospitals had better knowledge about the ER management of avulsion cases than those working in public hospitals.

To compare mean knowledge of different physicians' age, specialty, and experience level, Kruskal-Wallis $\mathrm{H}$ test was used. Results showed that there was a statistical significant difference between different age groups $(p=0.002)$, different specialties $(p=0.000)$, and different experience levels $(p=0.000)$.

\section{Comparisons within the groups (Table 6), (Table 7) and (Table 8)}

To compare mean knowledge of physicians within the groups, Bonferroni test was used at 5\% alpha error. There was a statistical significant difference between all age groups except between $(30-<40)$ and $(40-<50)$, and between $(40-<50)$ and $(\geq 50)$ groups (Table 6$)$. 
Table 4 Knowledge about tooth handling, cleaning and transport media

\begin{tabular}{|c|c|c|c|}
\hline Questions & Options & Frequency & Percent \\
\hline \multirow{6}{*}{$\begin{array}{l}\text { If you decided to replant the tooth into its socket, but it has fallen } \\
\text { onto the ground and is covered with dirt, what would you do? }\end{array}$} & Rinse tooth under running water & 59 & 48.4 \\
\hline & Gently wipe off the dirt that is stuck to the tooth by hand & 4 & 3.3 \\
\hline & Scrub the tooth gently with a toothbrush & 2 & 1.6 \\
\hline & Spray alcohol on the tooth & 15 & 12.3 \\
\hline & $\begin{array}{l}\text { Put the tooth straight back into the socket, with no } \\
\text { pretreatment }\end{array}$ & 2 & 1.6 \\
\hline & Don't know & 40 & 32.8 \\
\hline \multirow{9}{*}{$\begin{array}{l}\text { If you did not replant the tooth, How would you carry the tooth } \\
\text { to the dentist? }\end{array}$} & Wrap in paper or gauze & 26 & 21.3 \\
\hline & Pack the tooth in ice & 7 & 5.7 \\
\hline & Put in water & 10 & 8.2 \\
\hline & Put in milk & 38 & 31.1 \\
\hline & Put in saline & 26 & 21.3 \\
\hline & Put in alcohol & 3 & 2.5 \\
\hline & Put in disinfecting solution & 5 & 4.2 \\
\hline & Hold the tooth in the child's mouth & 0 & 0 \\
\hline & Missing & 7 & 5.7 \\
\hline \multirow[t]{4}{*}{ How to hold an avulsed tooth? } & From the crown & 63 & 51.6 \\
\hline & From the root & 2 & 1.6 \\
\hline & Anywhere (crown or root) & 11 & 9.1 \\
\hline & Don't know & 46 & 37.7 \\
\hline
\end{tabular}

In relation to different specialties, the highest mean knowledge was the ER physicians followed by pediatric physicians. There was a statistical significant difference between interns and the following two groups; the ER $(p=0.00)$ and pediatric physicians $(p=0.006)$ as well as between the general surgeons and ER physicians $(p=0.005)$ (Table 7).

In relation to the experience level of physicians (occupation), the highest mean knowledge was of the consultants, followed by the general practitioners (GPs), then specialists.
The lowest mean knowledge was of the interns followed by residents. There was a statistical significant difference between residents and the following senior physicians' groups; consultants $(p=0.00)$, specialists $(p=0.00)$ and GPs $(p=0.00)$ as well as between interns and; consultants $(p=0.00)$, specialist $(p=0.00)$ and GPs $(p=0.00)$ (Table 8$)$.

\section{Discussion}

This study provided a baseline information about the current level of knowledge of ER physicians about tooth

Table 5 Physicians Attitude

\begin{tabular}{|c|c|c|c|}
\hline Questions & Options & Frequency & Percent \\
\hline \multirow[t]{3}{*}{ What do you think is your level of information about traumatic dental injuries? } & Adequate & 29 & 23.8 \\
\hline & Inadequate & 77 & 63.1 \\
\hline & Don't know & 16 & 13.1 \\
\hline \multirow[t]{4}{*}{ In your opinion, learning about traumatic dental injuries is: } & Very important & 27 & 22.1 \\
\hline & Important & 95 & 77.9 \\
\hline & Somewhat important & 0 & 0 \\
\hline & Not important & 0 & 0 \\
\hline \multirow{2}{*}{$\begin{array}{l}\text { Would you like to receive more information in order to properly manage } \\
\text { traumatic dental injuries? }\end{array}$} & yes & 116 & 95.1 \\
\hline & no & 6 & 4.9 \\
\hline \multirow[t]{2}{*}{ Are you interested in knowing the emergency management of avulsed tooth? } & yes & 116 & 95.1 \\
\hline & no & 6 & 4.9 \\
\hline
\end{tabular}


Table 6 Bonferroni test for different age groups

\begin{tabular}{|c|c|c|c|c|c|c|}
\hline \multirow[t]{2}{*}{ (I) Age } & \multirow[t]{2}{*}{ (J) Age } & \multirow[t]{2}{*}{ Mean Difference (I-J) } & \multirow[t]{2}{*}{ Std. Error } & \multirow[t]{2}{*}{ Sig. } & \multicolumn{2}{|c|}{$95 \%$ Confidence Interval } \\
\hline & & & & & Lower Bound & Upper Bound \\
\hline \multirow[t]{3}{*}{$20-29$} & $30-39$ & $-21.56804^{*}$ & 3.50163 & .000 & -30.9673 & -12.1688 \\
\hline & $40-49$ & $-23.68827^{*}$ & 4.69053 & .000 & -36.2788 & -11.0977 \\
\hline & $>50$ & $-41.43519^{*}$ & 6.48089 & .000 & -58.8316 & -24.0388 \\
\hline \multirow[t]{3}{*}{ 30-39 } & $20-29$ & $21.56804^{*}$ & 3.50163 & .000 & 12.1688 & 30.9673 \\
\hline & $40-49$ & -2.12024 & 4.71825 & 1.000 & -14.7852 & 10.5448 \\
\hline & $>50$ & $-19.86715^{*}$ & 6.50099 & .017 & -37.3175 & -2.4168 \\
\hline \multirow[t]{3}{*}{$40-49$} & $20-29$ & $23.68827^{*}$ & 4.69053 & .000 & 11.0977 & 36.2788 \\
\hline & $30-39$ & 2.12024 & 4.71825 & 1.000 & -10.5448 & 14.7852 \\
\hline & $>50$ & -17.74691 & 7.21127 & .092 & -37.1038 & 1.6100 \\
\hline \multirow[t]{3}{*}{$>50$} & $20-29$ & $41.43519^{*}$ & 6.48089 & .000 & 24.0388 & 58.8316 \\
\hline & $30-39$ & $19.86715^{*}$ & 6.50099 & .017 & 2.4168 & 37.3175 \\
\hline & $40-49$ & 17.74691 & 7.21127 & .092 & -1.6100 & 37.1038 \\
\hline
\end{tabular}

avulsion. The results of the survey showed that nearly a third of physicians (31.1\%) did not know what an avulsed tooth was. This result was lower than Dali et al. [11] result where more than half of their participants did not know the meaning of tooth avulsion. Medical books and residency programs were the two major sources of knowledge for those who had previous information about the subject. Moreover, 59\% of the participants came across avulsion cases. However, $47.5 \%$ of them had no previous knowledge about its management. This result was in agreement with several previous studies done in Kuwait, USA, and Nepal where the percentage were $83.3 \%, 67 \%$, and $78.9 \%$ respectively $[9,11,13]$. These results reflect the importance of this study, since ER physicians are the first to contact and provide primary care for those cases.
Interestingly, there was a statistical significant difference in the level of knowledge between physicians working in military and public hospitals. Results showed that physicians working in military hospitals had better knowledge than those working in public hospitals. This might be attributed to the fact that military hospitals have more trauma cases than the other hospitals. However, this area needs further investigation. Moreover, there was a statistical significant difference between different age groups, different experience level and previous exposure to avulsion cases. All these differences are understandable and could be explained that with age, experience, as well as the exposure to avulsion cases, knowledge about ER management of avulsed tooth would increase.

The ideal treatment of tooth avulsion that determines long-term success is immediate replantation. The majority

Table 7 Bonferroni test for different specialty

\begin{tabular}{|c|c|c|c|c|c|}
\hline \multirow[t]{2}{*}{ Specialty } & \multirow[t]{2}{*}{ Specialty } & \multirow[t]{2}{*}{ Mean Difference } & \multirow[t]{2}{*}{ Std. Error } & \multirow[t]{2}{*}{ Sig. } & \multirow{2}{*}{$\begin{array}{l}\text { 95\% Confidence Interval } \\
\text { Lower Bound }\end{array}$} \\
\hline & & & & & \\
\hline \multirow[t]{3}{*}{$\mathrm{ER}$} & Pediatric & 10.11905 & 3.83961 & .057 & -.1844 \\
\hline & GS & $24.00794^{*}$ & 7.01014 & .005 & 5.1965 \\
\hline & Intern & $27.86596^{*}$ & 5.02529 & .000 & 14.3808 \\
\hline \multirow[t]{3}{*}{ Pediatric } & ER & -10.11905 & 3.83961 & .057 & -20.4225 \\
\hline & GS & 13.88889 & 7.18325 & .333 & -5.3871 \\
\hline & Intern & $17.74691^{*}$ & 5.26409 & .006 & 3.6209 \\
\hline \multirow[t]{3}{*}{ GS } & ER & $-24.00794^{*}$ & 7.01014 & .005 & -42.8194 \\
\hline & Pediatric & -13.88889 & 7.18325 & .333 & -33.1649 \\
\hline & Intern & 3.85802 & 7.88099 & 1.000 & -17.2903 \\
\hline \multirow[t]{3}{*}{ Intern } & ER & $-27.86596^{*}$ & 5.02529 & .000 & -41.3512 \\
\hline & Pediatric & $-17.74691^{*}$ & 5.26409 & .006 & -31.8729 \\
\hline & GS & -3.85802 & 7.88099 & 1.000 & -25.0064 \\
\hline
\end{tabular}


Table 8 Bonferroni test for different experience level (occupation)

\begin{tabular}{|c|c|c|c|c|c|}
\hline \multirow[t]{2}{*}{ Occupation } & \multirow[t]{2}{*}{ Occupation } & \multirow[t]{2}{*}{ Mean Difference } & \multirow[t]{2}{*}{ Std. Error } & \multirow[t]{2}{*}{ Sig. } & \multirow{2}{*}{$\begin{array}{l}\text { 95\% Confidence Interva } \\
\text { Lower Bound }\end{array}$} \\
\hline & & & & & \\
\hline \multirow[t]{4}{*}{ Consultant } & Specialist & 12.26852 & 5.21165 & .202 & -2.6433 \\
\hline & Resident & $31.01852^{*}$ & 4.66144 & .000 & 17.6810 \\
\hline & GP & 9.02778 & 5.70907 & 1.000 & -7.3073 \\
\hline & Intern & $40.66358^{*}$ & 5.54822 & .000 & 24.7888 \\
\hline \multirow[t]{4}{*}{ Specialist } & Consultant & -12.26852 & 5.21165 & .202 & -27.1803 \\
\hline & Resident & $18.75000^{*}$ & 4.03693 & .000 & 7.1994 \\
\hline & GP & -3.24074 & 5.21165 & 1.000 & -18.1525 \\
\hline & Intern & $28.39506^{*}$ & 5.03493 & .000 & 13.9889 \\
\hline \multirow[t]{4}{*}{ Resident } & Consultant & $-31.01852^{*}$ & 4.66144 & .000 & -44.3560 \\
\hline & Specialist & $-18.75000^{*}$ & 4.03693 & .000 & -30.3006 \\
\hline & GP & $-21.99074^{*}$ & 4.66144 & .000 & -35.3283 \\
\hline & Intern & 9.64506 & 4.46299 & .327 & -3.1246 \\
\hline \multirow[t]{4}{*}{ GP } & Consultant & -9.02778 & 5.70907 & 1.000 & -25.3628 \\
\hline & Specialist & 3.24074 & 5.21165 & 1.000 & -11.6711 \\
\hline & Resident & $21.99074^{*}$ & 4.66144 & .000 & 8.6532 \\
\hline & Intern & $31.63580^{*}$ & 5.54822 & .000 & 15.7610 \\
\hline \multirow[t]{4}{*}{ Intern } & Consultant & $-40.66358^{*}$ & 5.54822 & .000 & -56.5384 \\
\hline & Specialist & $-28.39506^{*}$ & 5.03493 & .000 & -42.8012 \\
\hline & Resident & -9.64506 & 4.46299 & .327 & -22.4148 \\
\hline & GP & $-31.63580^{*}$ & 5.54822 & .000 & -47.5106 \\
\hline
\end{tabular}

*The mean difference is significant at the 0.05 level

of the participants (79.5\%) thought it was possible to replant the avulsed tooth. However, $51.6 \%$ of them would not do it by themselves. This result was higher than Hashim's results [12] which showed that none of the participants preferred to put the tooth back into the socket before referring to the dentist. Similarly, several studies showed that the majority of participants would prefer to refer the patient to the dentist because they felt that those cases should be managed by dentists $[6,8,11]$. This was in agreement with the result of this study where $87.7 \%$ of the participants would refer or instruct the parents to visit the dentist after avulsion. However, $54 \%$ of them would advise the parents to go immediately. This was in consensus with Hashim's results [12] where 52\% of the physicians recognized the importance of immediate dental treatment. These results further indicated the needs and the importance of education since prognosis would be much better with immediate and appropriate treatment.

In relation to tooth handling, $51.6 \%$ of the physicians knew that the tooth should be held by the crown. This result was in agreement with Dali et al. [11] (50\%) and less than Jyothi et al. [6] (72.8\%). Furthermore, almost half of the physicians (48.4\%) chose to rinse the tooth under running water if it was covered with soil. Our results were less than Dali et al. [11] (84.7\%) and Jyothi et al. [6] (77.14\%) where most of their participants were aware that the tooth should be cleaned gently under running water to avoid damage to the periodontal cells.

Another factor that affects the prognosis and the success of treatment is the extra-oral time. Any delay in seeking professional treatment will jeopardize the prognosis. The optimum time for replantation is between 15 and $20 \mathrm{~min}$. In this study, $48.4 \%$ of the physicians did not know the importance of the extra-oral time. This was in consensus with other studies' results $[6,11]$.

If replantation is not feasible, the use of a correct transport media is an essential step, which will expand the extra-oral time to $1 \mathrm{~h}$. Transport media are used to maintain the periodontal ligament cells' viability, increase their survival and prevent any damage which might cause loss of the tooth in the future as ankylosis and resorption.

Theoretically, the best media for that function are HBSS, ViaSpan and Eagle's medium. However, they are not used because of their cost and unavailability for everyone. Practically, Milk is considered the best medium because of its convenience, cost and availability as well as its ability to preserve PDL cells viability $[3,6]$. It is an isotonic liquid with favorable osmolality, which has essential nutrients for periodontal ligament cells to survive and allow them to heal $[6,7]$. Therefore, it has been recommended as a 
temporary storage medium for avulsed teeth before replantation [14]. In our study, $31.1 \%$ of the participants chose milk as the best medium for storing the tooth. This result was similar to Ulusoy et al. [5], where $31.9 \%$ of the participants also chose milk as the best medium. However, our result was greatly higher than other studies $[11,12]$.

If replantation is not feasible, the use of a correct transport media is an essential step, which will expand the extra-oral time to $1 \mathrm{~h}$. This will maintain the periodontal ligament cells' viability and prevent any damage which might cause loss of the tooth in the future. Milk is considered the best medium for the periodontal ligament cells viability $[3,6]$. It is an isotonic liquid with favorable osmolality, which has essential nutrients for periodontal ligament cells to survive and allow them to heal $[6,7]$. Therefore, it has been recommended as a temporary storage medium for avulsed teeth before replantation [14]. In our study, $31.1 \%$ of the participants chose milk as the best medium for storing the tooth. This result was similar to Ulusoy et al. [5], where $31.9 \%$ of the participants also chose milk as the best medium. However, our result was greatly higher than other studies $[11,12]$.

Another aspect of this study was the participants' attitude towards learning about this subject. All the participants (100\%) agreed on the importance of learning about traumatic dental injuries. More than half of the participants (63.1\%) believed that they do not have adequate level of information about traumatic dental injuries. The majority of the participants $(95.1 \%)$ were keen to learn more about the management of avulsed teeth. Our results were in consensus with Ulusoy et al. [5] where $78.3 \%$ of the participants felt that they need further education about the subject.

\section{Conclusion}

The study findings showed that the majority of the ER physicians lack the knowledge needed to manage avulsion cases. The results stressed on the importance and the need of educating ER physicians about the emergency management of avulsed teeth. Traumatic dental injuries and the ER management should be integrated in the under graduate curriculum and post graduate programs to graduate physicians with an appropriate level of knowledge to manage ER cases.

\section{Additional file}

Additional file 1: The questionnaire used in the study. (PDF $214 \mathrm{~kb}$ )

\section{Abbreviations}

ER: Emergency room; GP: General practitioner; GS: General surgeon; HBSS: Hank's Balanced Salt Solution; PDL: Periodontal ligament

\section{Acknowledgements}

The author would like to thank Dr. Shahad Damanhouri and Dr. Arwa Abumansour for their contribution in data collection. In addition, the author wish to thank all the physicians who participated in the study.

\section{Funding}

Not applicable.

Availability of data and materials

The datasets generated and analyzed during the current study are available from the corresponding author on reasonable request.

\section{Author's contribution}

The author (LB) declare that she designed the study, the questionnaire, and the sampling. Also, she conducted and revised the statistical analysis and interpreted the results. Finally, she wrote the manuscript. The author read and approved the final manuscript.

\section{Ethics approval and consent to participate}

The study was ethically approved by the ethical committee, Faculty of Dentistry, King Abdulaziz University, Jeddah, S.A. Reference number (\#037-15). A consent form was attached to the questionnaire explaining the purpose of the study. It was stated that the participation in survey is voluntary and anyone can choose not to participate in the research or exit the survey at any time without penalty and the information provided by the participant in the questionnaire and the results of this study will be used for scholarly purposes only. Also, it was mentioned in the consent that; by answering the questionnaire questions the participant is fully understand the contents of this document and is agreeing to participate in this study.

\section{Competing interests}

The author declares that she has no competing interests.

\section{Publisher's Note}

Springer Nature remains neutral with regard to jurisdictional claims in published maps and institutional affiliations.

Received: 13 November 2017 Accepted: 19 March 2018

Published online: 02 April 2018

\section{References}

1. Blinkhorn FA. The aetiology of dento-alveolar injuries and factors influencing attendance for emergency care of adolescents in the north west of England. Dent Traumatol. 2000;16(4):162-5.

2. Andreasen JO, Andreasen FM. Textbook and color atlas of traumatic injuries to the teeth. Copenhagen: Blackwell Munksgaard; 2008.

3. Holan G, Shmueli Y. Knowledge of physicians in hospital emergency rooms in Israel on their role in cases of avulsion of permanent incisors. Int J Paediatr Dent. 2003;13(1):13-9.

4. Malmgren B, Malmgren $O$. Rate of infraposition of reimplanted ankylosed incisors related to age and growth in children and adolescents. Dent Traumatol. 2002;18(1):28-36.

5. Ulusoy AT, A-Nder H, Cetin B, Kaya Å. Knowledge of medical hospital emergency physicians about the first-aid management of traumatic tooth avulsion. Int J Paediatr Dent. 2012;22(3):211-6.

6. Jyothi KN, Venugopal P, Nanda S, Shah MK. Knowledge and attitude of medical doctors towards emergency management of avulsed tooth-a cross sectional survey. J Dent Sci Res. 2015;2:156-67.

7. Diaz J, Bustos L, Herrera S, Sepulveda J. Knowledge of the management of paediatric dental traumas by non-dental professionals in emergency rooms in South Araucania, Temuco, Chile. Dent Traumatol. 2009;25(6):611-9.

8. Subhashraj K. Awareness of management of dental trauma among medical professionals in Pondicherry, India. Dent Traumatol. 2009;25(1):92-4.

9. Abu Dawoud M, Al Enezi B, Andersson L. Knowledge of emergency management of avulsed teeth among young physicians and dentists. Dent Traumatol. 2007;23(6):348-55.

10. Stokes AN, Anderson HK, Cowan TM. Lay and professional knowledge of methods for emergency management of avulsed teeth. Dent Traumatol. 1992;8(4):160-2. 
11. Dali M, Naulakha D, Rajbanshi L. Practice in emergency management of avulsed tooth among medical doctors in Nobel medical college, Biratnagar, Nepal: A cross sectional survey. Int J Dent Heal Sci. 2014;1 (1):3-12.

12. Hashim R. Physicians' knowledge and experience regarding the management of avulsed teeth in United Arab Emirates. J Int Dent Med Resh. 2012:5(2):91-5.

13. Walker A, Brenchley J. It's a knockout: Survey of the management of avulsed teeth. Accid Emerg Nurs. 2000;8(2):66-70.

14. Poi WR, Sonoda CK, Martins CM, Melo ME, Pellizzer EP, Mendonca MR, et al. Storage media for avulsed teeth: A literature review. Braz Dent J. 2013;24(5): 437-45.

Submit your next manuscript to BioMed Central and we will help you at every step:

- We accept pre-submission inquiries

- Our selector tool helps you to find the most relevant journal

- We provide round the clock customer support

- Convenient online submission

- Thorough peer review

- Inclusion in PubMed and all major indexing services

- Maximum visibility for your research

Submit your manuscript at www.biomedcentral.com/submit 